\section{Increasing Crop Water Productivity through Local Crops and Technologies: A Case from the Ethnic Chepang Community of Nepal}

Bed P. Khatiwada, Rajan Ghimire, Rabindra Adhikari and Surendra Osti

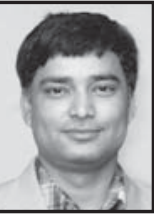

Bed P. Khatiwada

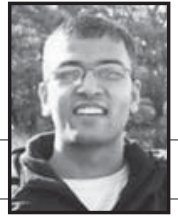

Rajan Ghimire

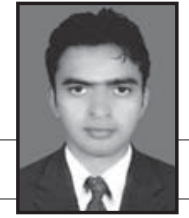

Rabindra Adhikar

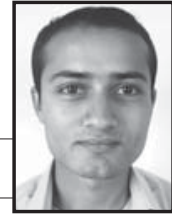

Surendra Osti

Abstract: Water is the most important and scarce production resource, and with changing climate the importance of this resource increases significantly. Increasing efforts are being made in research and education to maximize the water use efficiently with the concept of 'crop per drop' to increase crop water productivity with a good blend of science and indigenous knowledge. Nepalese farmers are adapting the best to water scarcity through adoption of sustainable soil management and the use of crops with minimum water requirement, among other options. This paper attempts to deal with the neglected issues of using local crops and indigenous knowledge and technologies for increasing water productivity.

Key words: Crops, water productivity, local crops, indigenous knowledge, indigenous technology, Chepang, Nepal

\section{Background and the Context}

G vidence from research and experiences from Efarming communities and others showed that agriculture is the key sector for water management, now and in the next decades. Water is the most crucial production input for agricultural system and determines the success or failure of crops. Increasingly, with changing climate and other associated uncertainties, the importance of water is increasing, leading to the emergence of the concept of water productivity or crop water productivity.

Crop water productivity is defined in terms of a systems approach, considering evapo-transpirational loss during production, which considers both transpiration from crop and evaporation from the soil. Simply stated, productivity is a ratio between a unit of output and a unit of input. Water productivity is used exclusively to denote the amount or value of production over volume or value of water diverted to produce certain amount of products.

The value of products might be expressed in different terms (biomass, grain, money). For example, the so-called 'crop per drop' approach focuses on the amount of product per unit of water. Another approach considers differences in the nutritional values of different crops, or that the same quantity of one crop feeds more people than the same quantity of another crop (FAO 2003). Water productivity is measured as kilogram per drop for comparing the productivity of water in different parts of the same system or river basin, and also for comparing the productivity of water in agriculture with other possible uses of water (FAO 2003).

Agricultural water productivity depends on soil and crop management practices. Water depletion occurs when water evaporates from moist soil, from puddles between rows and before crop establishment. All cultural and agronomic practices that reduce these losses, such as different row spacing, and application of mulches, improve water productivity. Similarly, drip irrigation has high water productivity as it causes much less soil wetting and less soil water loss than sprinkler irrigation systems.

Integrated crop and resource management practices, such as improved nutrient management, can improve water productivity by increasing the yield per unit water use. This principle applies to both irrigated and rainfed agriculture. Integrated weed and integrated pest management systems have also contributed effectively to yield increases.
Climate change is increasingly visible with impacts on crops, lives and livelihood assets. Water sources are depleting very fast along with depletion of soil moisture contents. The problem is further exacerbated by monocropping and extensive cultivation. Farmers are the most impacted by climate change, with direct impacts through flooding and droughts, and indirect impacts through increased temperature and change in moisture retention in soils. A majority of discussions on the issue, however, highlights the threats rather than developing alternatives.

Farmers have been practicing numerous techniques and testing them on their farms, thus shaping their agriculture in different twists and turns and best adapting to the environmental changes. But, these farmers' innovations are rarely documented. Adoption of sustainable technologies that farmers have been using for generations, technologies such as mulching, cover cropping and crop rotations, need to be documented and brought in mainstream research focus to minimize the risk of crop failure due to climate change.

In Nepal, farming relies on monsoon rain, fragile soils on steep mountains slopes and terrains as only $20 \%$ of our agricultural land is irrigated, and only $17 \%$ is relatively flat, in the lowland Terai. In this context, optimum utilization of the available water for increasing crop productivity with concept of 'crop per drop' is relevant. However, with increasing scarcity of water, harnessing water productivity in crop-livestock systems demands development of systems that include both indigenous development and local adaptation of exogenous interventions.

In drier areas, especially, where livelihood systems are highly vulnerable to climatic risks, where water is scarce and its availability is seasonal, successful local innovations often involve new ways of gaining access to or regulating use of water. In such systems, farmers are able to either find new ways to get water or to conserve water through diversification in farming practices. Therefore, local innovations through informal experimentation has always been taking place worldwide, and the scientific community has been paying more attention to identify and documentation such innovations these days with the objective of scaling up of the farmer led multi-stakeholder innovations (Reij and Waters-Bayer 2001) for better adaptation to the climate 
change or increasing environmental efficiencies of such techniques.

\section{Local Crops}

Water availability for farming is increasingly depleted with climate change. Accordingly, farming communities have practiced, tested and validated novel and innovative measures to adapt to changing climate. Study conducted on three different village development committees (VDCs) in Chitwan District, Nepal showed that 46 local crops are being used by ethnic Chepang communities for their food, nutrition and livelihood security. These local crops are intrinsically associated with the culture and become a part of their livelihood, and seem the best adapted even in the context of changing climate. These crops, which can perform better with low external inputs, are part of their farming system whether cultivated or harvested wild, based upon their locality and access to natural resources such as forests (Table 1). Moreover, these crops grow well under rainfed condition.

Besides, the farming communities cultivated different species of Dioscorea, for the purpose of meeting their daily dietary requirement. This single genus, being very hardy in nature and responsive to low external input conditions, can perform better in water scarce and sensitive soils.

Crops cultivated by the Chepang communities are lowexternal-input responsive crops and adapt to changing climates owing to their low water requirement and rainfed nature. In contrast, hybrids and improved varieties are never sustained in those farming system because of their high water requirement and other external inputs.

\section{Local Technologies \\ Minimum tillage and crop residue management including mulching}

Reduced exposure of soil through minimum soil disturbance and application of crop residue as mulch or their incorporation minimizes carbon release into the atmosphere on one hand, and increases soil organic matter on the other. Moreover, retention of plant residue with no tillage prevents soil erosion (up to 90\%), builds soil biodiversity, improves water infiltration (up to 60\%) for future crop use, and requires less energy for cultivation (McGarry 2009). This type of soil building/conserving practice is a common in Chepang communities in Chitwan. This innovation is a good adaptation of community to slopy lands and need for increasing soil organic matter in those remote areas where use of chemical fertilizers for nutrient management is not a feasible option.

\section{Crop rotation and mixed cropping}

Crop rotation is a practice of planting different crops in different season in a given unit of farm to avoid loss of crop from pests and climate hazards. Mixed cropping, on the other hand, is the practice of growing at least two crops together. Such practices include diverse crops, particularly legumes with non-legumes, deep rooted with shallow rooted, sun loving with shade loving, annuals with perennials, which increase soil fertility by improving soil physical, chemical, and biological properties. Crop rotation and mixed cropping has several other benefits to farmers.
Crops with allelopathic effects help in weed control thereby reducing the need for herbicides. Similarly, they reduce insect pest problems, thus assuring harvest of at least one crop, conserving the soil, and gradually increasing the agricultural system productivity. This supports farm economy, which is directly linked with better adaptation to climate change impacts. These measures seemed adopted in those fragile lands of Chepang communities and they were renovated on the basis of their location and indigenous knowledge system (Ghimire and Bista 2009).

\section{Agro-forestry}

Agro-forestry includes the practice of integrating trees into farming systems and agricultural landscapes, conversion of low-productive crop lands to sequential agro-forestry, and deforested forest to agro-forest. Here, perennial tree roots bind the soil and reduce erosion. Multipurpose trees (legumes) will fix atmospheric nitrogen and reduce demand for chemical fertilizers (Ghimire 2008). Increased biodiversity will help establish better predator prey relationship which will reduce requirement of chemical pesticides and herbicides. Multi-story cropping will increase resource use efficiency thereby increasing total production. Moreover, ethnic Chepang communities, being dependent upon the forest resources and being in close tie with forest resources as a part of their food, nutrition, and livelihood strategies, agroforestry is an attractive option (Ghimire and Bista 2009).

\section{Sloping Agricultural Land Technology (SALT)}

Sloping Agriculture Land Technology (SALT) is the method of growing field crops and permanent crops in three to five meter wide bands between contour hedgerows of nitrogen fixing trees. Nitrogen fixing trees add nitrogen to the soil, and their cut leaves and twigs cover the soil minimizing the erosion due to rainfall while functioning as an excellent organic fertilizer. The crop rotation technique of SALT will maintain soil health and control insect pest populations so that additional pesticides are not required. Sloping Agriculture Land Technology and eco-friendly vegetable production practices in Kabilash, Chitwan District of Nepal became successful in minimizing soil fertility degradation and soil loss through erosion, leading to higher farm productivity, increased farm income maintain a safe and health y environment (Ghimire 2008, Ghimire and Bista 2009). The various conservation agriculture practices have supported farm economy and ecology, the two important bases for higher resilience to climate change. Thus, conservation agriculture technology has high potential for adaptation to climate change impacts.

\section{Policy and Practice}

Nepal has experienced an average maximum annual temperature increase of $0.06^{\circ} \mathrm{C}$. This rate of increase is higher in the mountains than in other regions. Despite having only $0.4 \%$ of the total global population and being responsible for only $0.025 \%$ of total greenhouse gas (GHG) emissions in the world, Nepal will be affected disproportionately, especially from increasing atmospheric temperature. Changes in an annual rainfall cycle, intense rainfall and longer droughts have been observed. 


\begin{tabular}{|c|c|c|c|c|c|}
\hline $\begin{array}{c}\text { S. } \\
\text { No. }\end{array}$ & $\begin{array}{l}\text { Nepali } \\
\text { Name }\end{array}$ & $\begin{array}{c}\text { Chepang } \\
\text { Name }\end{array}$ & $\begin{array}{c}\text { English } \\
\text { Name }\end{array}$ & $\begin{array}{c}\text { Scientific } \\
\text { Name }\end{array}$ & $\begin{array}{l}\text { Growth } \\
\text { Habit* }\end{array}$ \\
\hline 1 & ainselu & lyangsai & raspberry & Rubus ellipticus Sm. Rosaceae & $\mathrm{P}$ \\
\hline 2 & amaro & pakmaru & golden apple & Spondias cytherea Sonn. Anacardiaceae & $\mathrm{P}$ \\
\hline 3 & amrisho & phek & broom grass & Thysanolaena maxima (Roxb.) Kuntze Poaceae & $\mathrm{P}$ \\
\hline 4 & ban kera & banmaisai & banana & Musa balbisiana Colla. Musaceae & $\mathrm{P}$ \\
\hline 5 & ban tarul & brangoi & wild yam & Dioscorea bulbifera L. Dioscoreaceae & $\mathrm{P}$ \\
\hline 6 & bankakri & banaisai & - & Solena heterophylla Lour.Cucurbitaceae & A \\
\hline 7 & bans & chyas & bamboo & Bambusa nepalensis Stapleton Poaceae & $\mathrm{P}$ \\
\hline 8 & bel & bel & wood apple & Aegle marmelos (L.) Corrêa Rutaceae & A \\
\hline 9 & bethe sag & bethu & lamb's quarter & Chenopodium album L. Chenopodiaceae & A \\
\hline 10 & bhakyamlo & rusai & Nepalese sumac & Rhus javanica L. Anacardiaceae & $\mathrm{P}$ \\
\hline 11 & bhimsen pati & goihomro & Butterfly bush & Buddleja asiatica Lour. Scrophulariaceae & $\mathrm{P}$ \\
\hline 12 & bhorla & maklo & Camel's foot climber & Bauhinia vahlii Wight \& Am. Fabaceae & A \\
\hline 13 & bhyakur & pass & Cush-cush yam & Dioscorea deltoidea Wall. ex Griseb. Dioscoreaceae & A P \\
\hline 14 & camuna & camuna & - & Syzygium cerasoides (Roxb.) Raizada Myrtaceae & $\mathrm{P}$ \\
\hline 15 & chilaune & kyangsi & Needle wood & Schima wallichii (DC.) Korth. Theaceae & $\mathrm{P}$ \\
\hline 16 & chiuri & yosai & Butter tree & Diploknema butyracea (Roxb.) H.J. Lam Sapotaceae & $\mathrm{P}$ \\
\hline 17 & dumri & dumri & Cluster fig & Ficus racemosa L. Moraceae & $\mathrm{P}$ \\
\hline 18 & githa & lak & Air potato & Dioscorea bulbifera L. Dioscoreaceae & A \\
\hline 19 & jaluko & fyaksa & - & Remusatia vivipara (Roxb.) Schott Araceae & A \\
\hline 20 & jamun & - & Black plum & Eugenia formosa Wall. Myrtaceae. & $\mathrm{P}$ \\
\hline 21 & jangali aanp & bantaksai & Wild mango & Mangifera indica L. Anacardiaceae & $P$ \\
\hline 22 & jaringo & - & Poker weed & Phytolacca acinosa Roxb.Phytolaccaceae & A P \\
\hline 23 & kabro & kabra & Elephant fig & Ficus lacor Buch.-Ham. Moraceae & $\mathrm{P}$ \\
\hline 24 & kaphal & kaphal & Box myrtle & Myrica esculenta Buch.-Ham. ex D. Don Myrtcaceae & A \\
\hline 25 & katus & ekai & Chestnut & Castanopsis indica (Roxb. ex Lindl.) A. DC. Fagaceae & $\mathrm{P}$ \\
\hline 26 & khaniyo (rai) & koksai & - & Ficus semicordata Buch.-Ham.ex Sm. Moraceae & $\mathrm{P}$ \\
\hline 27 & khole sag & simsag & Brooklime & Veronica beccabunga L. Scrophulariaceae & A \\
\hline 28 & koiralo & rimsi & - & Bauhinia purpurea L. Fabaceae & $\mathrm{P}$ \\
\hline 29 & kurilo & jyordum & Wild asparagus & Asparagus racemosus Willd. Asparagaceae & A P \\
\hline 30 & kutilkosa & nakatisai & Clover vetch & Vicia angustifolia L. ex Reichard Fabaceae & A \\
\hline 31 & latte sag & dakhinsag & Amaranth & Amaranthus spinosus L. Amaranthaceae & A \\
\hline 32 & lunde & armulya & Pigweed & Amaranthus viridis L. Amaranthaceae & A \\
\hline 33 & nigalo & monyanro & Himalayan bamboo & Arundinaria falcata Nees Poaceae & $\mathrm{P}$ \\
\hline 34 & nimaro & nemsi & eve's & Ficus auriculata Lour. & $\mathrm{P}$ \\
\hline 35 & niuro & niuro & edible fern & Dryopteris cochleata (D. Don) C. Chr. Dryopteridaceae & A \\
\hline 36 & pakhanbed & pakhanbed & rock foil & Bergenia ciliata (Haw.) Sternb. Saxifragaceae & $\mathrm{P}$ \\
\hline 37 & pandel & yausi & - & Ziziphus incurva Roxb. Rhamnaceae & $\mathrm{P}$ \\
\hline 38 & raikhanyu & koksi & Nepal fodder fig & Ficus semicordata Buch.-Ham. ex Sm. Moraceae & $\mathrm{P}$ \\
\hline 39 & shiplican & dyoyaisag & Garlic pear & Crataeva unilocularis Buch.-Ham. Capparaceae & $\mathrm{P}$ \\
\hline 40 & simali & glausigoi & Orange jasmine & Murraya paniculata (L.) Jack Rutaceae & $\mathrm{P}$ \\
\hline 41 & sisno & nelau & Nettle & Urtica dioica L. Urticaceae & $\mathrm{P}$ \\
\hline 42 & siundi & kituki & - & Euphorbia sp. Euphorbiaceae & $\mathrm{P}$ \\
\hline 43 & tanki & saga & Pink bauhinia & Bauhinia purpurea L. Fabaceae & $\mathrm{P}$ \\
\hline 44 & timoor & umpur & Nepal pepper & Zanthoxylum armatum DC. Rutaceae & $\mathrm{P}$ \\
\hline 45 & tindu & tindu & tindu & Diospyros malabarica (Desr.) Kostel. Ebenaceae & A \\
\hline 46 & tyaguna & - & - & Dioscorea pentaphylla L. Dioscoreaceae & A \\
\hline
\end{tabular}

Table 1. List of Local Crops Used by Chepang Communities of Chitwan District, Nepal. 
Similarly, both days and nights are presently warmer. The number of days with $100 \mathrm{~mm}$ of heavy rainfall is increasing (Dahal, Pokharel and Pandey 2011; Shrestha, Wake et al 1999). The timing and duration of rainfall is also changing. As glaciers recede from rapid snow and ice melting, glacier lakes are expanding.

The adverse impacts of climate change have been noticed in agriculture and food security, water resources, forests and biodiversity, health, tourism and infrastructures. Climate-induced disasters and other effects have caused damages and losses to life, property, and livelihoods.

\section{National Agriculture Policy, 2005}

National Agricultural Policy, 2005 which updates the Agricultural Perspective Plan (APP), places commercialization, private sector-led development, and trade at the forefront of the development agenda. This policy has the vision of improving living standard through sustainable agricultural development achieved by commercial and competitive farming system.

The main objectives of this policy are to:

- increase production and productivity,

- increase competitiveness in regional and world markets developing foundations of commercial and competitive agriculture, and

- protect, promote and utilize existing natural resources, environment and biodiversity.

\section{Climate Change Policy Nepal, 2011}

Climate Change Policy Nepal, 2011 prioritizes promotion of local crops along with local sustainable technologies to adapt to climate change as given in the following paragraphs. This aims at promoting climatefriendly natural resources management practices with focus on:

- developing and implementing a scientific land use system,

- proper utilization, promotion, conservation of forest resources as a means of alternative livelihoods,

- prioritizing and implementing programmes on the sustainable management of forests, agro-forestry, pasture, rangeland, and soil conservation that can address the impacts of climate change,

- conserving soil and water through measures such as source protection, rain water harvesting, and environmental sanitation,

- encouraging carbon sequestration and investing some of the benefits from the use of forest products for controlling forest fires and conserving forests, and

- adopting a basin approach for water management through regular monitoring of water resource availability.

\section{National Agro Biodiversity Policy, 2007}

This policy, with the main efforts on conserving agricultural biodiversity, was formulated and the positive impacts of agricultural biodiversity have been realized in terms of increased resilience of changing shocks created by climate change, among several other benefits. This policy aims at promoting in situ and ex situ conservation. However, the real program formulation and implementation mechanism is yet to be observed.

\section{Conclusions and Recommendations}

Water productivity is defined as the ratio of net benefits from crop, forestry, fishery, livestock, and mixed agricultural systems to the amount of water required to produce those benefits. It reflects the objective of producing the most food, income, livelihoods and ecological benefits at the least social and environmental cost per unit of water used. Farmers, through hundreds of years of experience and continuous search for technologies to shape their agriculture, give birth to a new innovation. Such innovations, however, have been neglected by the current research, education and extension systems. One conspicuous example is indigenous knowledge and innovations found in the ethnic Chepang communities of Nepal. The Chepang communities of Chitwan District have been using 46 different local crops for their food, nutrition and livelihood security and adopting different conservation measures. These local crops along with sustainable farming techniques like agro forestry, SALT and crop rotation have only been promoted in certain areas under piloting initiative or programmatic intervention rather than mentioning in policy for systematic efforts of promoting those techniques. Therefore, there is scope for researching possibilities of promoting such technologies and local crops to increase water productivity, climate change adaptation and livelihood security of marginalized Chepang community of Nepal.

Bed Prasad Khatiwada is an agriculturist currently working with ActionAid International Nepal as Theme Leader of Right to Food and Land, and providing strategic directions and technical input to work on food, land, agriculture and livelihood initiatives of ActionAid Nepal.

Corresponding address: BedPrasad.Khatiwada@ actionaid.org

Rajan Ghimire is a PhD candidate at the University of Wyoming, USA. He is conducting his research on the impact of crop rotation on soil carbon sequestration. His prior experience is in organic and sustainable agriculture while working in Nepal as Lecturer in Institute of Agriculture and Animal Science, and as a program officer at the Ecological Services Center.

Rabindra Adhikari is a Masters student and researcher at the University of Ghent, Belgium, under the Physical Land Resource Program with a major in Soil Science. His research interests and experiences are in the dynamics of soil water and soil carbon for sustainable agriculture.

Surendra Osti a freelancer conducting research on natural resource management, including minor crops, plant clinics and health problems, their impact upon food security along with other issues of livelihood, and natural resource governance.

...Continued on Page 58 